\title{
Hvordan støtte foreldre til barn med livsforkortende sykdom?
}

\author{
Når et barn diagnostiseres med en livsforkortende sykdom, rammes hele familien hardt. Hvordan opplever \\ foreldre å få en slik beskjed? Hva kan vi som helsepersonell gjøre for å støtte foreldrene når barnet blir dia- \\ gnostisert med en sjelden progredierende tilstand?
}

Torun Marie Vatne

tva@frambu.no

En diagnose regnes som sjelden når det er færre enn 500 som har den i befolkningen $(1: 10$ 000). Mer enn 30000 mennesker i Norge lever med en sjelden diagnose, og mange av disse er barn. Flere av disse sykdommene har et progredierende forløp hvor barnet har en normal utvikling tidlig i livet. Sykdommene kan være muskulære, for eksempel Duchennes muskeldystrofi, nevrologiske, for eksempel nevronal ceroid lipofusinose, eller metabolske, for eksempel adrenoleukodystrofi (1).

\section{Jakten på en diagnose}

Fra foreldrene fatter mistanke om at noe er galt, til en sjelden diagnose stilles, kan veien være kort og brutal, men den kan også være lang og krevende. Ettersom sjeldne diagnoser nettopp er sjeldne, vil de fleste leger aldri før ha møtt en pasient med den aktuelle diagnosen. Mistanke vil derfor ofte ikke vekkes, og dermed blir ikke nødvendige tester gjennomført (2). Foreldre kan føle seg avvist som «overbekymrede foreldre», og ganske mange forteller at bekymringene deres rundt barnas første symptomer ikke ble lyttet til (3).

Jakten på en diagnose kan være svært stressende for foreldrene (4), men foreldrene kan også være nyttige bidragsytere gjennom sine søk på internett (2). Informasjonen de finner, bør tas alvorlig og inngå i dialogen med legen (5). Klinisk erfaring tilsier at å bli hørt og tatt på alvor med sine mistanker er viktig for å bevare et tillitsfullt forhold til helsevesenet.

Underveis i en utredning fatter kanskje legen mistanke om en konkret diagnose og beslutter å gjøre en spesifikk diagnostisk test. En viktig overveielse er da om man skal informere foreldrene om hvorfor testen gjennomføres. Ofte har ikke foreldrene hørt om diagnosen før den stilles (3), men blir de spurt, ønsker de ofte informasjon om diagnosen før testing og å kunne påvirke når og hvor mye informasjon som blir gitt.
Foreldrene forteller at det er viktig å bli møtt med empati, håp og vennlighet når informasjon gis. Vi vet at behovet for informasjon og emosjonell støtte ved diagnosetidspunkt henger tett sammen med foreldrenes forhåndskunnskap og følelsesmessige tilstand (6).

\section{Formidling}

«De sa ikke på nyhetene at verden raste sammen i dag» (7). Hvordan et barns diagnose ble formidlet, og hvordan sjokket rammet, er en hendelse og et minne som kan påvirke familiens mestring av det nye hverdagslivet (8). Det er viktig at foreldrene făr den informasjonen de ønsker, at de forstår den og at de husker den i etterkant. De akutte stressreaksjonene som utløses, kan imidlertid utfordre informasjonsflyten (3). Med visse grep kan man tilrettelegge situasjonen bedre.

Basert på en gjennomgang av forskningen på feltet utviklet Boyd (9) følgende retningslinjer for diagnoseformidling ved barnenevrologiske avdelinger: Hold møtet med foreldrene så raskt som mulig etter at diagnosen er bekreftet - i en skjermet, hyggelig setting. $\mathrm{Be}$ om at begge foreldrene er til stede eller at enslige foreldre har med en støtteperson. Den som holder møtet, bør kjenne familien og ha høy kompetanse på diagnosen. Eventuelle andre deltagere bør ha deltatt i den diagnostiske prosessen. Formidle diagnosen tidlig i møtet, og spør så foreldrene om deres kjennskap til diagnosen. Gi tilpasset informasjon om prognose, utvikling, behandling og ytelser. Bygg håp ved å referere til erfaring og forskning. Lytt til foreldrenes uttrykk for følelser. Gi dem informasjon om eventuelle tjenester de henvises videre til, og formidle kontakt med brukerforeninger ved ønske om dette. Tilby foreldrene å få den informasjonen som er blitt gitt under møtet, skriftlig, og gi dem mulighet for en ny samtale ved en senere anledning. Når man avslutter, bør foreldrene gis mulighet til å være for seg selv i et skjermet rom.

Helsepersonell har plikt til å sørge for at barn får god informasjon om sin diagnose (pasientrettighetsloven § 3-4 og 3-5). Om barnet skal være med når diagnosen formid- les, bør derfor vurderes. En godt forberedt lege kan, ved å formidle diagnosen til familien samlet, bidra til at en felles forståelse og åpenhet etableres. Hvis barnet er med til sykehuset, men ikke med i konsultasjonen, bør man ha planlagt hvordan barnet skal ivaretas. Foreldre som må gå rett ut til barnet sitt etter å ha fått formidlet en alvorlig diagnose, opplever ofte dette som svært vanskelig (3). Det er derfor viktig at avdelingen har ressurser tilgjengelig til å ivareta barnet ved behov.

Det er av stor betydning at man veileder foreldre i hvordan man kan snakke med barna (også søsken) om diagnosen. Dette er spesielt avgjørende hvis ikke barnet er med ved diagnoseformidlingen. Mange foreldre er usikre og ønsker råd. Barna vet at de har vært hos legen til undersøkelser, og de merker ofte at foreldrene er lei seg. Det første steget til å informere barnet kan derfor være å fortelle at legen har funnet ut at det har en sykdom, og at foreldrene naturlig nok er triste på grunn av denne beskjeden. Den viktigste informasjonen man gir, er knyttet til det barnet merker av symptomer eller hemninger i hverdagen og håndteringen av dette (10).

Informasjon er en prosess hvor helsepersonell må støtte foreldre i å ta valg som er riktige for familien på ulike tidspunkter $i$ livet. Det finnes mange muligheter mellom «å fortelle alt» og «fortie», og for de fleste familier blir veien til mens man går. Dersom barnet har en sjelden sykdom, kan kompetansetjenesten for sjeldne diagnoser kontaktes for råd og veiledning (11).

Trening kan øke legers ferdigheter $\mathrm{i}$ å snakke med foreldre og barn om progredierende diagnoser (12). Det er viktig at avdelingen prioriterer dette. Når en diagnose skal formidles, bør legen forberede hva som skal sies, og hvordan egne og andres reaksjoner kan håndteres (13). Det er ikke uvanlig å håndtere vanskelige følelser som helsepersonell ved å gi mer informasjon (14), men foreldrene trenger en lege som lytter og viser empati (15). For å klare dette trengs det kollegastøtte. Dersom man fortrenger vanskelige følelser som oppstår i utfordrende møter med pasienter, er det 


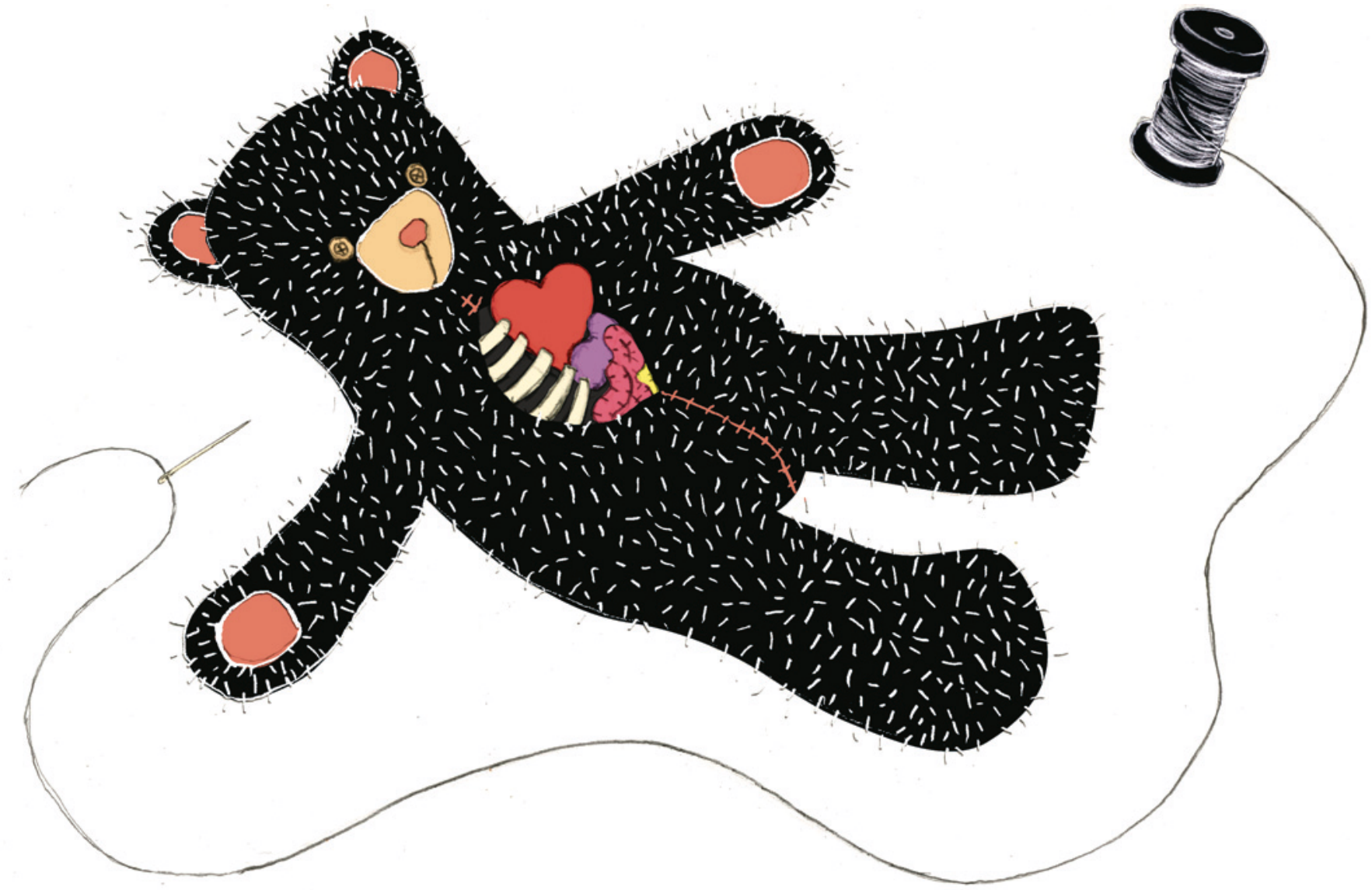

Illustrasjon: Sylvia Stølan

større risiko for senere emosjonell utmattelse enn dersom man søker støtte (16).

\section{Støtte til foreldre}

Krisereaksjonene foreldrene opplever ved diagnosetidspunkt, kan føles skremmende. Informasjon om normale reaksjoner kan forhindre tilleggsbelastningen ved å bekymre seg for egne reaksjoner (17), og det anbefales i de nasjonale retningslinjene for krisehåndtering (18). Legen bør ta opp betydningen av rutiner, mat og søvn i hverdagen som kommer, og hvordan familie eller venner eventuelt kan bidra med praktisk hjelp. For noen foreldre vil de umiddelbare reaksjonene være så sterke at det er behov for kontakt med psykisk helsevern. Min erfaring er at kriseteam $\mathrm{i}$ både kommunen og spesialisthelsetjenesten kan stå parat hvis de får adekvat informasjon om diagnosens traumatiske natur.

Også i den videre oppfølgingen av barna bør foreldrenes tilpasning vies oppmerksomhet. Økt aktivering, muskelspenninger, søvnproblemer, mageproblemer og svekket immunforsvar er vanlige fysiske reaksjoner. Påtrengende minner, konsentrasjons- og hukommelsesproblemer, uvirkelighetsføl- else eller fastlåste tankemønstre er vanlige mentale reaksjoner. Et naturlig forløp ved kriser er at mennesket skånes litt $\mathrm{i}$ begynnelsen, og at de sterke følelsesmessige reaksjonene først kommer etter en stund (19). De som ikke trengte psykologisk støtte og veiledning $\mathrm{i}$ begynnelsen, kan få behov for det senere.

Ventesorg er et begrep som er blitt brukt om den prosessen foreldre til barn med kortere forventet levetid går inn i, og som kan innebære mange av de samme tankene, følelsene og reaksjonene som man opplever etter at et dødsfall har funnet sted (20). $\AA$ være foreldre i denne situasjonen er ekstremt belastende, men foreldre beskriver også hvordan tiden får en annen verdi, at opplevelsen av å leve blir sterkere og at dagene også kan oppleves som gode (21).

Foreldrenes opplevelse av mestring henger sammen med hvilke ressurser de har tilgang til, men mange har høy terskel for å søke hjelp (21). Helsepersonell bør også bidra med informasjon og råd til nettverket rundt familien, eventuelt $i$ samarbeid med aktuelt kompetansesenter for sjeldne diagnoser (11). Støttesamtaler gitt av kommunehelsetjenesten (se psykisk helsehjelp på kommunenes nettsider) kan være en god støtte til foreldre, barn og søsken. Ved psykologiske vansker som påvirker funksjon i hverdagslivet, er spesialisthelsetjenesten riktig instans. I henvisningen til fastlegen kan det da være hensiktsmessig at legespesialisten skriver en uttalelse om diagnosens natur.

\section{Konklusjon}

God ivaretakelse av foreldrene er en investering $\mathrm{i}$ barnets og familiens fremtid sammen. Vi som arbeider med familier som blir kastet ut i sitt livs mareritt, vet hvor kloke og robuste både foreldre og barn kan være. God diagnoseformidling, familiefokus i oppfølgingen, involvering av psykiske helsetjenester og godt tverretatlig samarbeid er viktig for å støtte disse familiene.

\section{Torun Marie Vatne (f. 1978)}

er psykologspesialist, ph.d. og ansatt ved Frambu kompetansesenter for sjeldne diagnoser.

Forfatter har fylt ut ICMJE-skjemaet og oppgir ingen interessekonflikter. 


\section{Litteratur}

1. Frambu kompetansesenter for sjeldne diagnoser. http://frambu.no/diagnoser (3.4.2017).

2. Bouwman MG, Teunissen QG, Wijburg FA et al. 'Doctor Google' ending the diagnostic odyssey in lysosomal storage disorders: parents using internet search engines as an efficient diagnostic strategy in rare diseases. Arch Dis Child 2010; 95: 642-4.

3. Green JM, Murton FE. Diagnosis of Duchenne muscular dystrophy: parents' experiences and satisfaction. Child Care Health Dev 1996; 22 : 113-28.

4. Firth MA. Diagnosis of Duchenne muscular dystrophy: experiences of parents of sufferers. $\mathrm{Br}$ Med J (Clin Res Ed) 1983; 286: 700-1.

5. Tang $\mathrm{H}, \mathrm{Ng} \mathrm{JH}$. Googling for a diagnosis-use of Google as a diagnostic aid: internet based study. BMJ 2006; 333: 1143-5.

6. Tluczek A, Koscik RL, Modaff P et al. Newborn screening for cystic fibrosis: parents' preferences regarding counseling at the time of infants' sweat test. J Genet Couns 2006; 15: 277-91.

7. Boge ATN. De sa ikke på nyhetene. I Haug M, Hoem B, red. Annerledeslandet. Dikt om liv som tok uventede veier. Siggerud: Frambu, 2012: 7 .

8. Krahn GL, Hallum A, Kime C. Are there good ways to give 'bad news'? Pediatrics 1993; 91: 578-82.
9. Boyd JR. A process for delivering bad news: supporting families when a child is diagnosed. J Neurosci Nurs 2001; 33: 14-20.

10. Vatne TM, Helmen $\emptyset \emptyset$, Bahr D et al. «She came out of mum's tummy the wrong way». (Mis)conceptions among siblings of children with rare disorders. J Genet Couns 2015; 24: 247-58.

11. Nasjonal kompetansetjeneste for sjeldne diagnoser (NKSD) https://helsenorge.no/sjeldne-diagnoser (5.1.2017).

12. Greenberg LW, Ochsenschlager D, O'Donnell R et al. Communicating bad news: a pediatric department's evaluation of a simulated intervention. Pediatrics 1999; 103: 1210-7.

13. Baile WF, Buckman R, Lenzi R et al. SPIKES-A sixstep protocol for delivering bad news: application to the patient with cancer. Oncologist 2000; 5: 302-11.

14. Andræ M. Facing death: physicians' difficulties and coping strategies in cancer care. Umeå university medical dissertations, new series no 395 ISSN

0346-6612. Department of psychiatry Umeå university and Department of Education, Uppsala University, Sweden,1994.

15. VandeKieft GK. Breaking bad news. Am Fam Physician 2001: 64: 1975-8

16. Wallace JE, Lemaire J. Physician coping styles and emotional exhaustion. Ind Relat 2013; 68: 187-209.
17. McNally RJ. Psychological mechanisms in acute response to trauma. Biol Psychiatry 2003; 53: 779-88.

18. Helsedirektoratet. Veileder for psykososiale tiltak ved kriser, ulykker og katastrofer. Oslo: Helsedirektoratet, 2011.

19. Traumer. Bergen: Senter for krisepsykologi, 2017. https://krisepsyk.no/tema/traumer/ \#vanligereaksjoner (5.2.2017)

20. Sweeting HN, Gilhooly ML. Anticipatory grief: a review. Soc Sci Med 1990: 30: 1073-80.

21. Grasaasen A. Hverdagsliv og ventesorg. Hvordan leves livet på lånt tid? Et foreldreperspektiv. Masteroppgave. Oslo: Diakonhjemmet Høgskole, 2015

Mottatt 5.1. 2017, første revisjon innsendt 4.4. 2017, godkjent 5.4. 2017. Redaktør: Ketil Slagstad. Engelsk oversettelse på www.tidsskriftet.no 